\title{
Chiral Symmetry Breaking of Racemic 3-Phenylsuccinimides via Crystallization-Induced Dynamic Deracemization
}

\author{
Kazutaka Sanada, Aoi Washio, Kazuki Nishihata, Fumitoshi Yagishita, \\ Yasushi Yoshida, Takashi Mino, Shinichi Suzuki, Yoshio Kasashima, \\ and Masami Sakamoto*
}

Department of Applied Chemistry and Biotechnology, Graduate School of Engineering, Chiba University, Yayoi-cho, Inage-ku, Chiba 263-8522, Japan

E-mail: sakamotom@faculty.chiba-u.jp 


\section{Table of Contents}

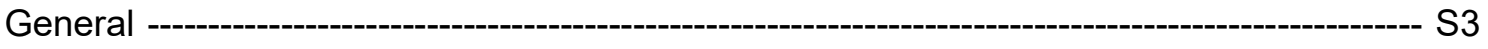

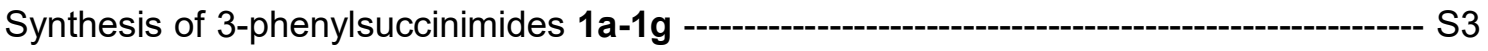

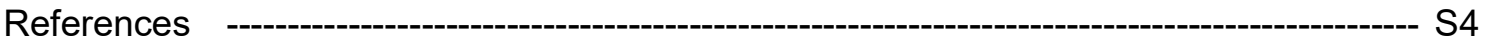

Single crystal X-ray structure analysis of $1 \mathrm{a}-1 \mathrm{~g} \quad$ -

Racemization of $\mathbf{1 b}$ and $1 f$

Crystallization-Induced dynamic preferential optical resolution of $\mathbf{1 b}$ and $\mathbf{1 f}$---------- S13

Viedma ripening of $\mathbf{1 b}$ and $\mathbf{1 f}$

HPLC analysis of $\mathbf{1 b}$ and $1 f$

Spectral chart of 3-phenylsuccinimides of $\mathbf{1 b}$ and $\mathbf{1 f}$ 


\section{General}

NMR spectra were recorded in $\mathrm{CDCl}_{3}$ solutions on Bruker DPX 300 and DPX 400 spectrometers for ${ }^{1} \mathrm{H}$ - and ${ }^{13} \mathrm{C}$ - NMR. Chemical shifts are reported in parts per million (ppm) relative to TMS as an internal standard. HPLC analyses were performed on a JASCO HPLC system (JASCO PU-1580 pump, DG-1580-53, LG-2080-02, MD-2015, UV-2075, and CD2095 detector). Commercially available 3-phenylsuccinic anhydride, amines, acetic acid, and 1,8-diazabicyclo[5.4.0]undec-7-ene (DBU) were used without further purification. Chiral column CHIRALPAK IC and IA (Daicel Ind.) were used for HPLC analysis.

All 3-phenylsuccinimides 1a-g were synthesized from 3-phenylsuccinic anhydride and corresponding amines. ${ }^{[1]}$ The structure was confirmed by the comparison of the reported spectral data. 1a, ${ }^{[1 \mathrm{a}]} \mathbf{1 b},{ }^{[1 \mathrm{a}]} \mathbf{1 c},{ }^{[2]} \mathbf{1 d},{ }^{[3]} \mathbf{1 e},{ }^{[4]} \mathbf{1 f}$ (new), $\mathbf{1 g}{ }^{[4]}$ Finally all structures were unequivocally determined by single crystal $\mathrm{X}$-ray structure analysis.

\section{Synthesis of 3-phenylsuccinimides 1a-g}

All 3-phenylsuccinimides were synthesized as the same methodology exemplified by the synthesis of $\mathbf{1 b}$.

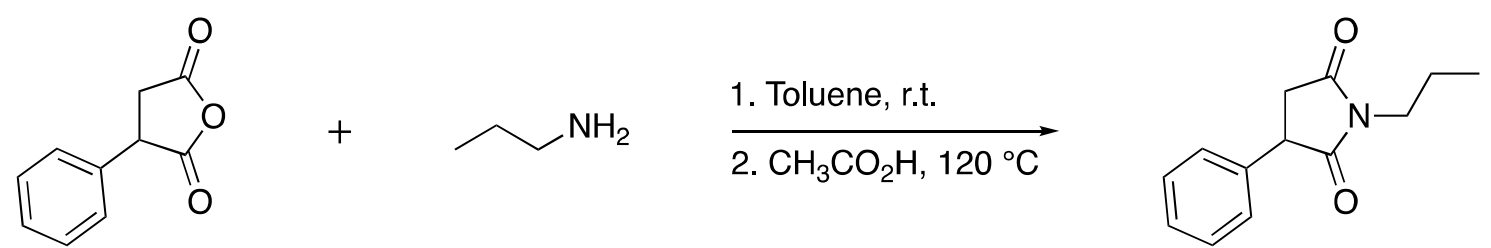

3-Phenylsuccinic anhydride $(6.3 \mathrm{~g}, 35 \mathrm{mmol})$ and $n$-propylamine $(2.3 \mathrm{~g}, 38.5 \mathrm{mmol})$ were dissolved in toluene $(140 \mathrm{~mL})$, and then stirred at room temperature for $2 \mathrm{~h}$. After the crystalline adduct was filtered and dried under reduced pressure, the solid was mixed with acetic acid for 12 hours at $120^{\circ} \mathrm{C}$. After acetic acid was evaporated under reduced pressure, the residual crude solid was recrystallized from $\mathrm{CHCl}_{3}$ and hexane to give a colourless solid of $1 \mathrm{~b}$ in $54 \%(4.0 \mathrm{~g}, 19 \mathrm{mmol})$ yield.

\section{3-Phenyl-1-propylpyrrolidine-2,5-dione 1b}

Colourless solid: $\mathrm{mp} 63-64{ }^{\circ} \mathrm{C}$ (racemic): IR (KBr) $1697 \mathrm{~cm}^{-1}:{ }^{1} \mathrm{H}$ NMR $\left(\mathrm{CDCl}_{3}\right) \delta 0.93$ (t, $\mathrm{J}=$ $7.4 \mathrm{~Hz}, 3 \mathrm{H}), 1.59-1.71(\mathrm{~m}, 2 \mathrm{H}), 2.77-2.85(\mathrm{~m}, 1 \mathrm{H}), 3.15-3.25(\mathrm{~m}, 1 \mathrm{H}), 3.55(\mathrm{t}, \mathrm{J}=7.4 \mathrm{~Hz}, 3 \mathrm{H})$, 3.98-4.03 (m, 1H), 7.20-7.40 (m, 5H); ${ }^{13} \mathrm{C}$ NMR $\left(\mathrm{CDCl}_{3}\right) \delta$ 11.2, 21.0, 37.1, 40.6, 45.8, 127.3, 
127.9, 129.1, 137.4, 176.2, 177.7; HRMS (ESI-MS) m/z calcd for $\mathrm{C}_{13} \mathrm{H}_{15} \mathrm{O}_{2} \mathrm{~N}+\mathrm{Na} 240.0995$ found 240.0991 .

After deracemization: Optical rotation: $[\alpha]^{20} \mathrm{D}+6.917(99 \%$ ee $)\left(\mathrm{c}=1.1\right.$ in $\left.\mathrm{CHCl}_{3}\right): \mathrm{mp} 89-90{ }^{\circ} \mathrm{C}$ (99\% ee).

\section{1-(3-Methoxyphenyl)-3-phenylpyrrolidine-2,5-dione $1 f$}

Colourless solid: mp. $107-108{ }^{\circ} \mathrm{C}$ (racemic), IR (KBr) $1703 \mathrm{~cm}^{-1}:{ }^{1} \mathrm{H}$ NMR $\left(\mathrm{CDCl}_{3}\right) \delta 2.95-$ $3.03(\mathrm{~m}, 1 \mathrm{H}), 3.32-3.42(\mathrm{~m}, 1 \mathrm{H}), 3.81(\mathrm{~s}, 3 \mathrm{H}), 4.16-4.21(\mathrm{~m}, 1 \mathrm{H}), 6.85-6.97(\mathrm{~m}, 3 \mathrm{H}), 7.30-$ $7.43(\mathrm{~m}, 6 \mathrm{H}) ;{ }^{13} \mathrm{C} \mathrm{NMR}\left(\mathrm{CDCl}_{3}\right) \delta 37.2,45.9,55.4,112.3,114.6,118.7,127.4,128.0,129.3$, 129.9, 132.8, 137.1, 160.1, 175.1, 176.5; HRMS (ESI-MS) $\mathrm{m} / \mathrm{z}$ calcd for $\mathrm{C}_{17} \mathrm{H}_{15} \mathrm{O}_{3} \mathrm{~N}+\mathrm{Na}$ 304.0944 found 304.0937 .

After deracemization: Optical rotation: $[\alpha]^{20} \mathrm{D}-2.019\left(99 \%\right.$ ee) $\left(\mathrm{c}=3.0\right.$ in $\left.\mathrm{CHCl}_{3}\right)$ : $\mathrm{mp} 133-$ $134{ }^{\circ} \mathrm{C}(99 \%$ ee $)$.

\section{References}

[1] (a) C. A. Miller, L. M. Long, J. Am. Chem. Soc., 1951, 73, 4895-4898.; (b) C. A. Miller, H. I. Scholl, L. M. Long, J. Am. Chem. Soc. 1951, 73, 5608-5610; (c) K. Kaminski, J. Obniska, I. Chlebek, B. Wiklik, S. Rzepka, Bioorg. Med. Chem., 2013, 21, 6821.

[2] R. Shintani, W.-L. Duan, T. Nagano, A. Okada, T. Hayashi, Angew. Chem. Int. Ed. 2005, 44, 4611-4614.

[3] H. Liu, G. P. S. Lau, P. J. Dyson, J. Org. Chem. 2015, 80, 386-391.

[4] N. Perisic-Janjic, R. Kaliszan, P. Wiczling, N. Milosevic, G. Uscumlic, N. Banjac, Mol. Pharmaceutics 2011, 8, 555-563. 
Single crystal X-ray structure analysis of $\mathbf{1 a - 1 g}$

Single crystal X-ray structure analysis of 1a (CCDC2102521)

Colourless block, $\left(0.20 \times 0.20 \times 0.10 \mathrm{~mm}^{3}\right)$, monoclinic space group $P 2_{1} / \mathrm{c}, a=10.645(3) \AA, b=$ $6.3080(19) \AA, c=13.971(4) \AA, \beta=93.854(4)^{\circ}, V=936.0(5) \AA^{3}, Z=4, \lambda($ MoKa $)=0.71073 \AA, \rho$ $=1.343 \mathrm{~g} / \mathrm{cm}^{3}, \mu=0.093 \mathrm{~mm}^{-1}, 5112$ reflections measured $\left(T=173 \mathrm{~K}, 2.923^{\circ}<\theta<27.541^{\circ}\right)$, $\mathrm{nb}$ of independent data collected: $2118, \mathrm{nb}$ of independent data used for refinement: $1760 \mathrm{in}$ the final least-squares refinement cycles on $\mathrm{F}^{2}$, the model converged at $R_{1}=0.0406, w R_{2}=$ $0.1008[\mathrm{l}>2 \sigma(\mathrm{I})], R_{1}=0.0491, w R_{2}=0.1059$ (all data), and GOF $=1.055, \mathrm{H}$-atom parameters constrained.
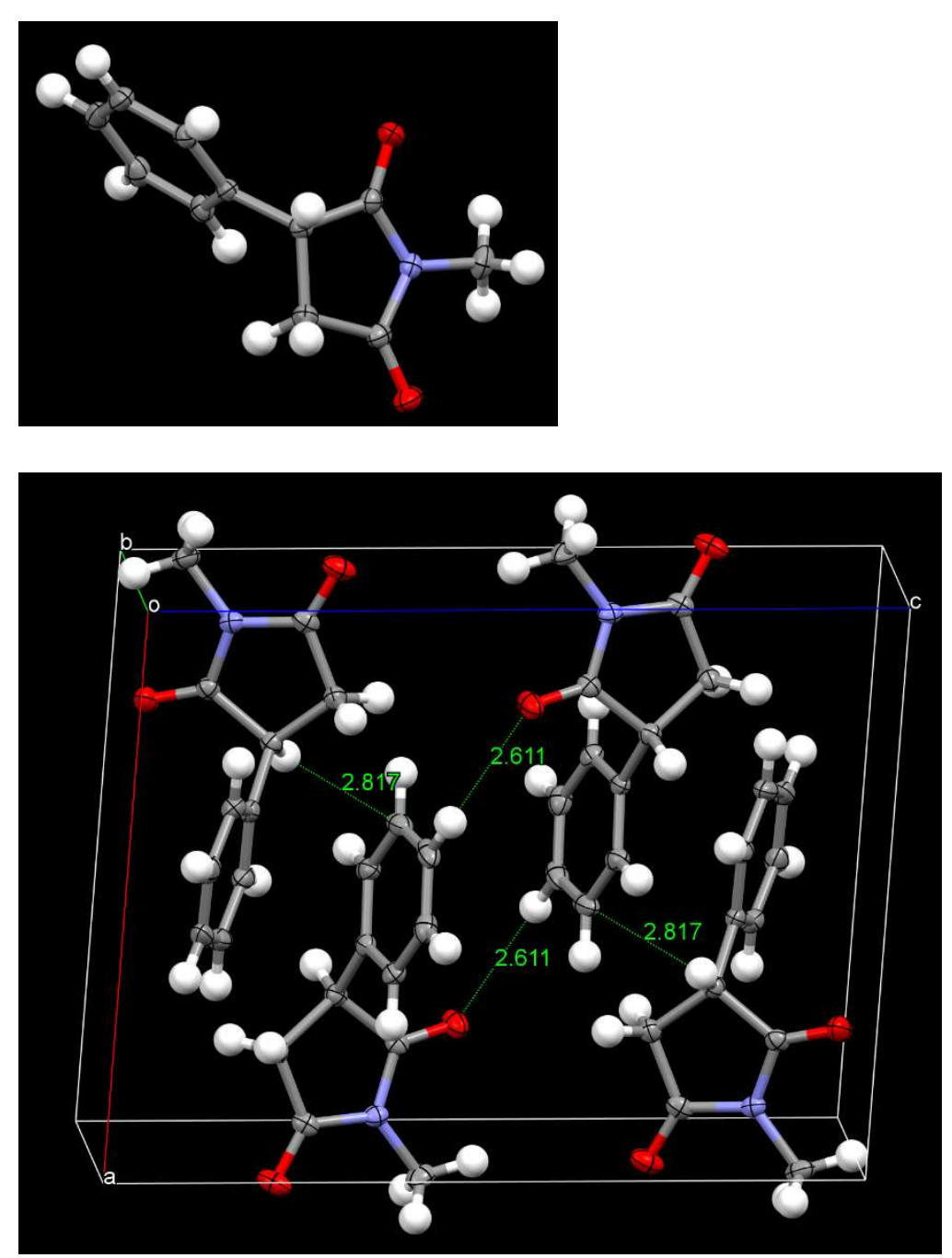

Figure S1. Perspective view and the packing diagram of 1a 
Single crystal X-ray structure analysis of $\mathbf{1 b}$ (CCDC2102522)

Colourless block, $\left(0.30 \times 0.30 \times 0.10 \mathrm{~mm}^{3}\right)$, orthorhombic space group $P 2{ }_{1} 2_{1} 2_{1}, a=5.436(2) \AA$, $b=8.208(4) \AA, c=25.760(11) \AA, V=1149.4(8) \AA^{3}, Z=4, \lambda($ MoKa $)=0.71073 \AA, \rho=1.256 \mathrm{~g} / \mathrm{cm}^{3}$, $\mu=0.085 \mathrm{~mm}^{-1}, 5452$ reflections measured $\left(\mathrm{T}=173 \mathrm{~K}, 1.581^{\circ}<\theta<25.213^{\circ}\right)$, nb of independent data collected: 2073, nb of independent data used for refinement: 1890 in the final least-squares refinement cycles on $\mathrm{F}^{2}$, the model converged at $R_{1}=0.0306, w R_{2}=$ $0.0748[\mathrm{I}>2 \sigma(\mathrm{I})], R_{1}=0.0342, w R_{2}=0.0767$ (all data), and GOF $=1.080, \mathrm{H}$-atom parameters constrained.
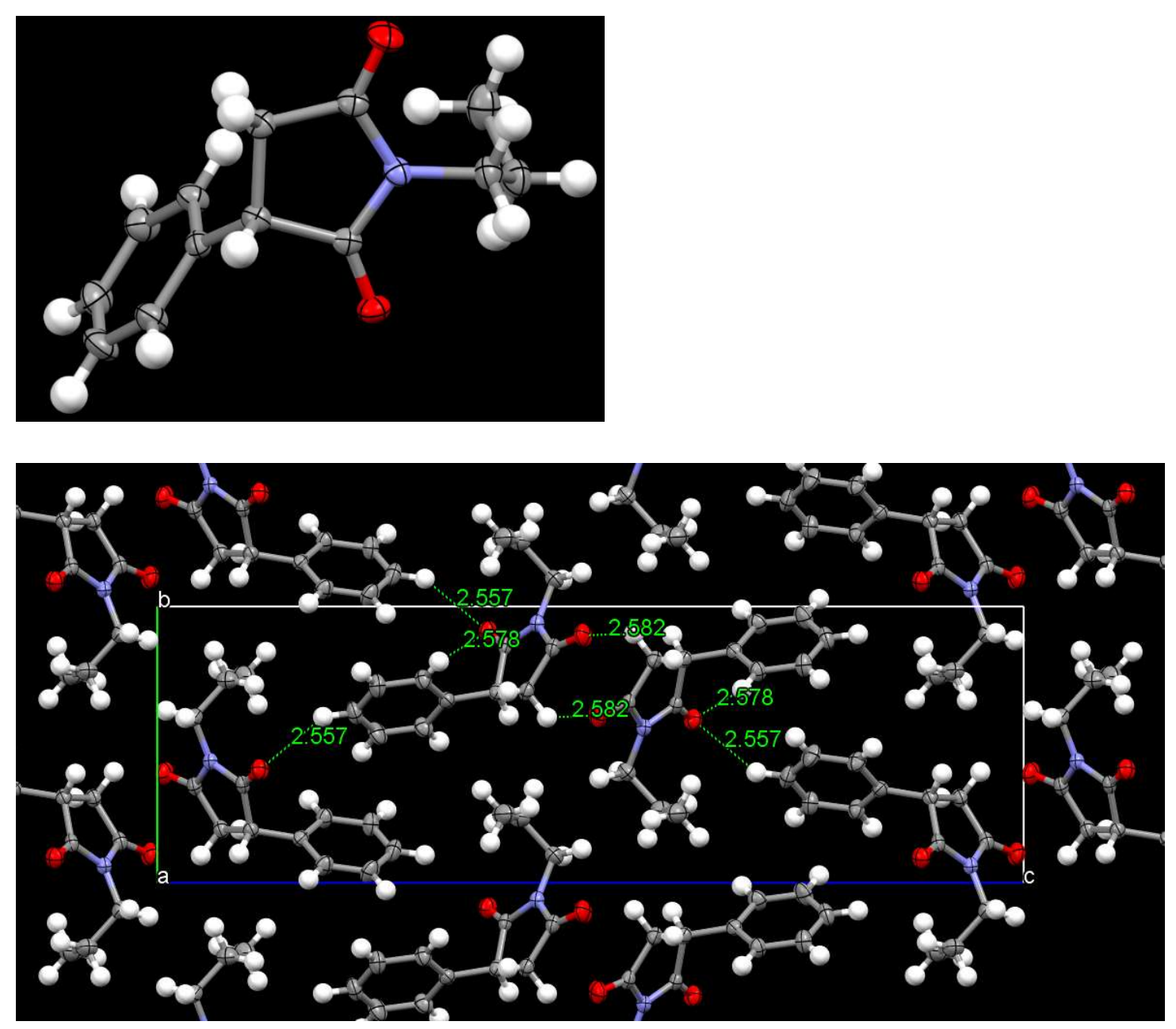

Figure S2. Perspective view and the packing diagram along a-axis of $\mathbf{1 b}$ 
Single crystal X-ray structure analysis of 1c (CCDC2102523)

Colourless block, $\left(0.20 \times 0.20 \times 0.10 \mathrm{~mm}^{3}\right)$, monoclinic space group $P 2_{1} / \mathrm{c}, a=8.507(3) \AA, b=$ $6.311(2) \AA, c=24.375(8) \AA, \beta=98.045(4)^{\circ}, V=1295.8(7) \AA^{3}, Z=4, \lambda(\mathrm{MoK \alpha})=0.71073 \AA, \rho=$ $1.288 \mathrm{~g} / \mathrm{cm}^{3}, \mu=0.085 \mathrm{~mm}^{-1}, 6823$ reflections measured $\left(\mathrm{T}=173 \mathrm{~K}, 1.687^{\circ}<\theta<27.617^{\circ}\right)$, $\mathrm{nb}$ of independent data collected: 2960, $\mathrm{nb}$ of independent data used for refinement: 1662 in the final least-squares refinement cycles on $\mathrm{F}^{2}$, the model converged at $R_{1}=0.0577, w R_{2}=$ $0.1401[\mathrm{I}>2 \sigma(\mathrm{I})], R_{1}=0.1114, w R_{2}=0.1780$ (all data), and GOF $=0.983, \mathrm{H}$-atom parameters constrained.
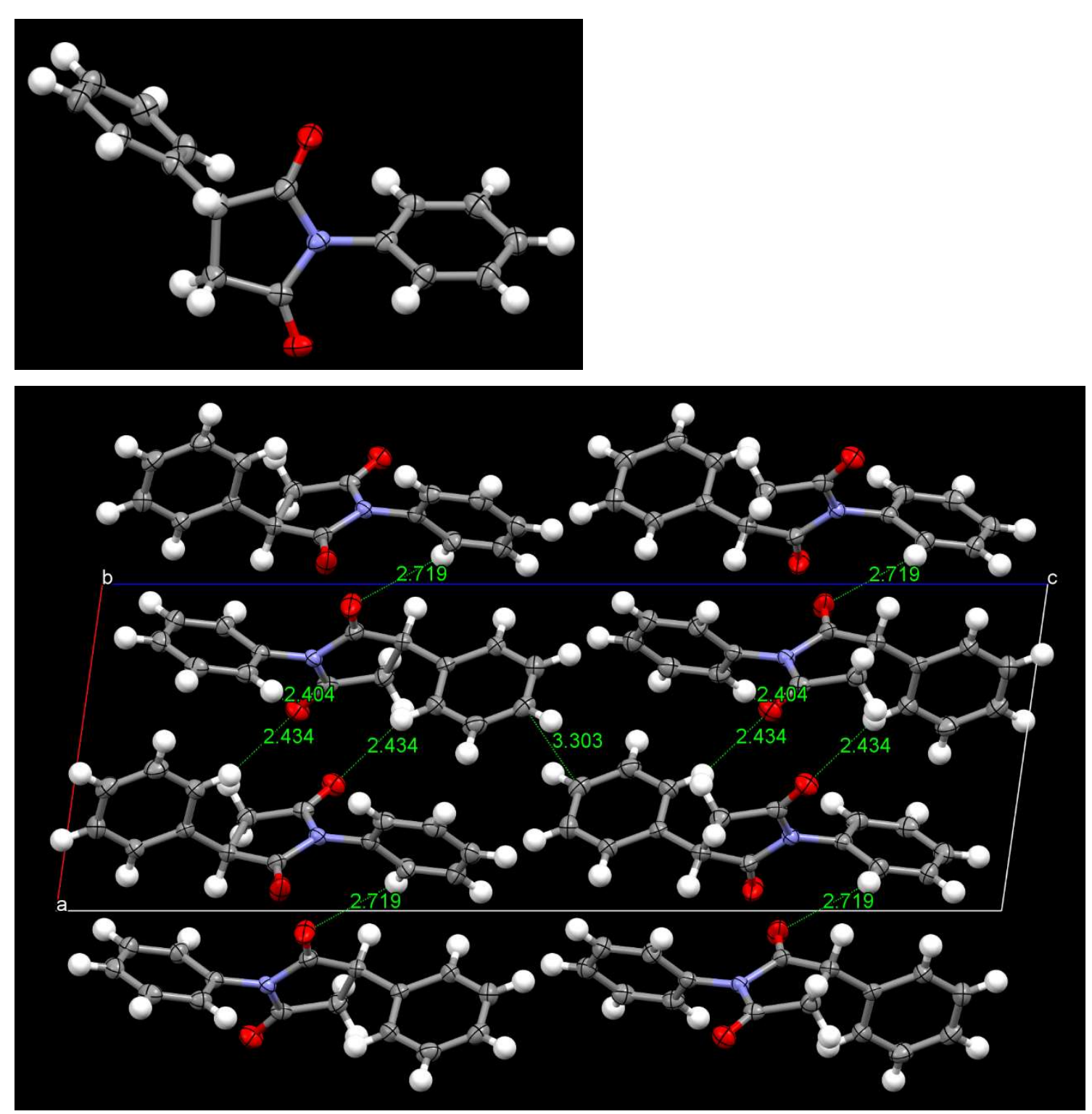

Figure S3. Perspective view and the packing diagram along $b$-axis of 1c 
Single crystal X-ray structure analysis of 1d (CCDC2102525)

Colourless block, $\left(0.20 \times 0.20 \times 0.20 \mathrm{~mm}^{3}\right)$, monoclinic space group $P 2_{1} / \mathrm{c}, a=12.022(2) \AA, b=$ $5.6057(10) \AA, c=20.981(4) \AA, \beta=105.926(3)^{\circ}, V=1359.7(4) \AA^{3}, Z=4, \lambda(\mathrm{MoK \alpha})=0.71073 \AA$, $\rho=1.296 \mathrm{~g} / \mathrm{cm}^{3}, \mu=0.085 \mathrm{~mm}^{-1}, 7554$ reflections measured $\left(T=173 \mathrm{~K}, 2.019^{\circ}<\theta<27.771^{\circ}\right)$, $\mathrm{nb}$ of independent data collected: $3116, \mathrm{nb}$ of independent data used for refinement: 1627 in the final least-squares refinement cycles on $\mathrm{F}^{2}$, the model converged at $R_{1}=0.0617, w R_{2}=$ $0.1072[\mathrm{I}>2 \sigma(\mathrm{I})], R_{1}=0.1374, w R_{2}=0.1360$ (all data), and GOF $=1.021, \mathrm{H}$-atom parameters constrained.
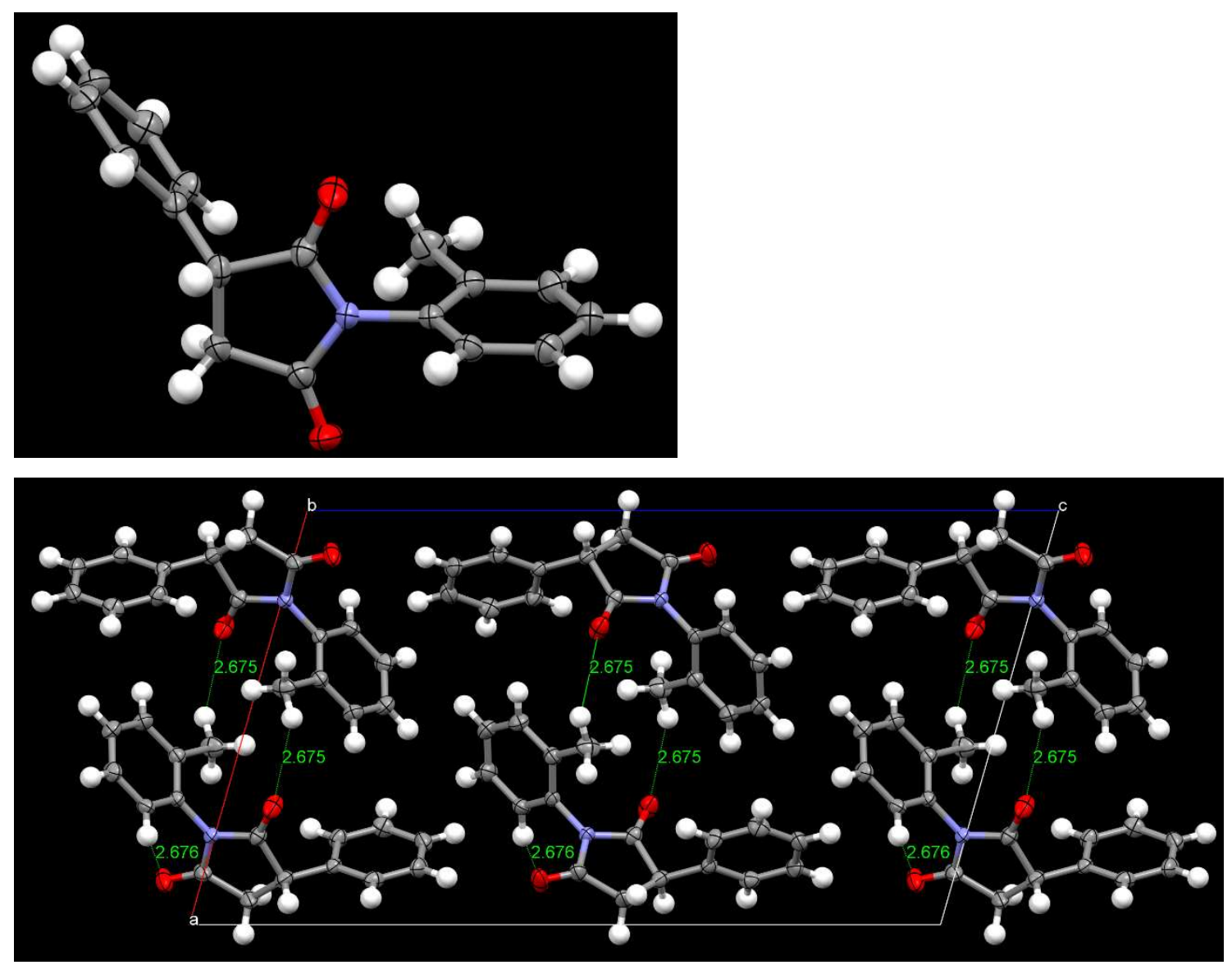

Figure S4. Perspective view and the packing diagram of 1d 
Single crystal X-ray structure analysis of 1e (CCDC2102526)

Colourless block, $\left(0.20 \times 0.20 \times 0.10 \mathrm{~mm}^{3}\right)$, orthorhombic space group $P$ ca2 $2_{1}, a=26.564(4) \AA$, $b=8.4016(17) \AA, c=6.4000(10) \AA, V=1428.4(4) \AA^{3}, Z=4, \lambda($ CuKa $)=1.54178 \AA, \rho=1.234$ $\mathrm{g} / \mathrm{cm}^{3}, \mu=0.649 \mathrm{~mm}^{-1}, 6706$ reflections measured $\left(\mathrm{T}=173 \mathrm{~K}, 3.327^{\circ}<\theta<68.224^{\circ}\right)$, nb of independent data collected: $2140, \mathrm{nb}$ of independent data used for refinement: 1592 in the final least-squares refinement cycles on $\mathrm{F}^{2}$, the model converged at $R_{1}=0.0785, w R_{2}=0.1824$ $[\mathrm{I}>2 \sigma(\mathrm{I})], R_{1}=0.1042, w R_{2}=0.1950$ (all data), and GOF $=1.133, \mathrm{H}$-atom parameters constrained.
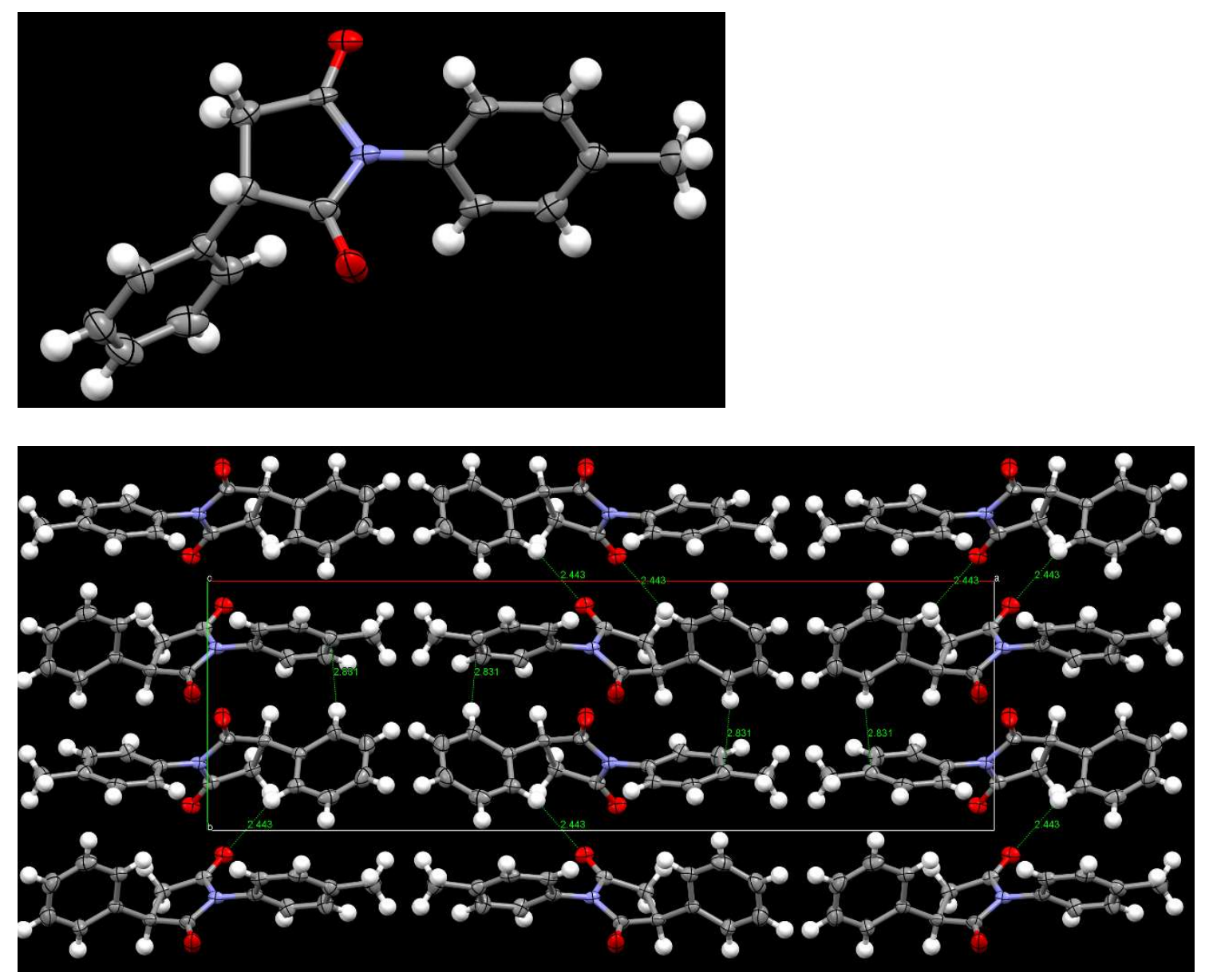

Figure S5. Perspective view and the packing diagram of 1e 
Single crystal X-ray structure analysis of $1 \mathrm{f}(\mathrm{CCDC} 2102527)$

Colourless block, $\left(0.20 \times 0.20 \times 0.20 \mathrm{~mm}^{3}\right)$, monoclinic space group $P 2_{1}, a=8.084(8) \AA, b=$ 6.646(6) $\AA, c=13.535(13) \AA, \beta=106.929(10)^{\circ}, V=695.7(11) \AA^{3}, Z=2, \lambda(\mathrm{MoK \alpha})=0.71073$ $\AA, \rho=1.343 \mathrm{~g} / \mathrm{cm}^{3}, \mu=0.093 \mathrm{~mm}^{-1}, 1892$ reflections measured $\left(T=173 \mathrm{~K}, 1.573^{\circ}<\theta<\right.$ $\left.27.643^{\circ}\right), \mathrm{nb}$ of independent data collected: 1419, $\mathrm{nb}$ of independent data used for refinement: 958 in the final least-squares refinement cycles on $\mathrm{F}^{2}$, the model converged at $R_{1}=0.0479, w R_{2}=0.1116[\mathrm{I}>2 \sigma(\mathrm{I})], R_{1}=0.0714, w R_{2}=0.1191$ (all data), and GOF $=0.895$, $\mathrm{H}$-atom parameters constrained.
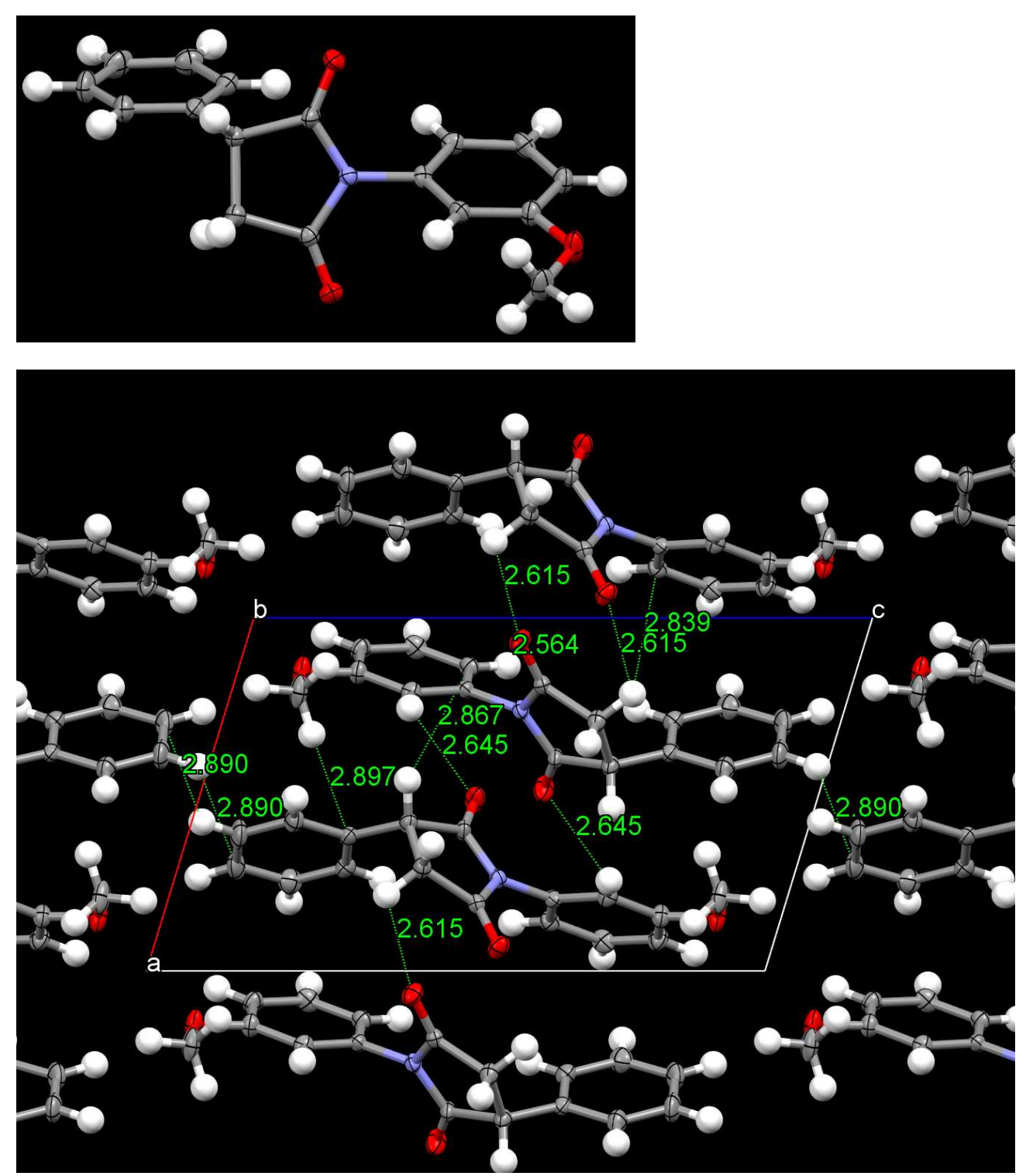

Figure S6. Perspective view and the packing diagram of $\mathbf{1 f}$ 
Single crystal X-ray structure analysis of $\mathbf{1 g}$ (CCDC2102528)

Colourless block, $\left(0.20 \times 0.20 \times 0.10 \mathrm{~mm}^{3}\right)$, orthorhombic space group Pbca, $a=6.9850(15) \AA$, $b=16.257(3) \AA, c=24.417(5) \AA, V=2772.7(10) \AA^{3}, Z=8, \lambda($ MoKa $)=0.71073 \AA, \rho=1.369$ $\mathrm{g} / \mathrm{cm}^{3}, \mu=0.275 \mathrm{~mm}^{-1}, 15090$ reflections measured $\left(\mathrm{T}=173 \mathrm{~K}, 1.668^{\circ}<\theta<27.762^{\circ}\right), \mathrm{nb}$ of independent data collected: $3236, \mathrm{nb}$ of independent data used for refinement: 1734 in the final least-squares refinement cycles on $\mathrm{F}^{2}$, the model converged at $R_{1}=0.0552, w R_{2}=0.1288$ $[\mathrm{I}>2 \sigma(\mathrm{I})], R_{1}=0.1195, w R_{2}=0.1752$ (all data), and GOF $=0.968, \mathrm{H}$-atom parameters constrained.
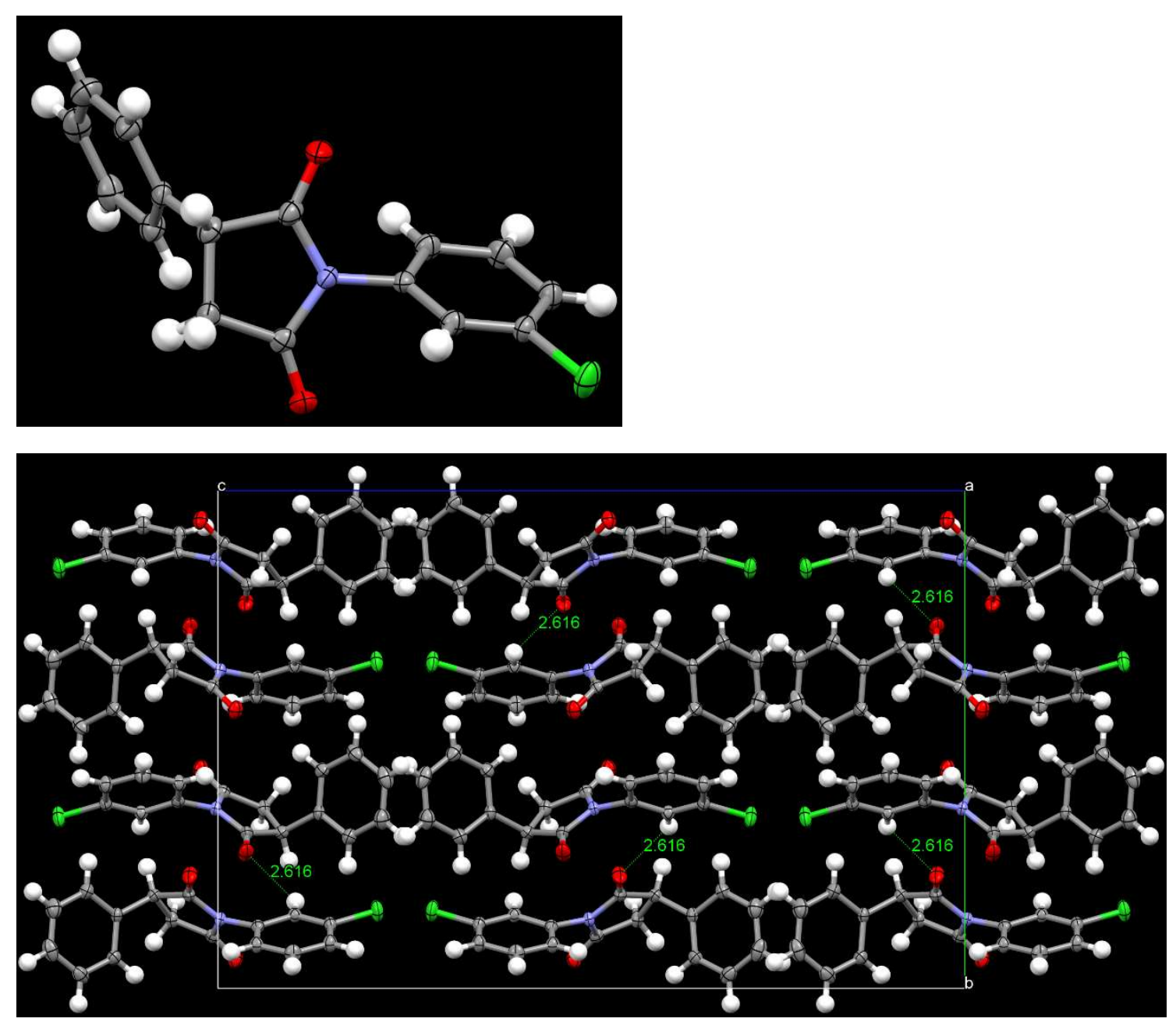

Figure S7. Perspective view and the packing diagram of $\mathbf{1 g}$ 


\section{Racemization of $1 \mathrm{~b}$ and $1 \mathrm{f}$.}

Various solutions of $1 \mathbf{b}$ and $1 \mathrm{f}(0.01 \mathrm{M})$ and $\mathrm{DBU}(0.15 \mathrm{mg}, 0.001 \mathrm{mmol})$ were kept at $20^{\circ} \mathrm{C}$. The time course of enantiomeric excess was monitored by HPLC (1b: CHIRALPAK IC, hexane: 2-PrOH = $80: 20$, flow $0.5 \mathrm{~mL} / \mathrm{min}, \mathrm{RT}=17.7$ and $26.2 \mathrm{~min} .1 \mathrm{f}:$ CHIRALPAK IA, hexane: $\mathrm{EtOH}=50: 50$, flow $1.0 \mathrm{~mL} / \mathrm{min}, \mathrm{RT}=14.2$ and $23.5 \mathrm{~min}$ ).

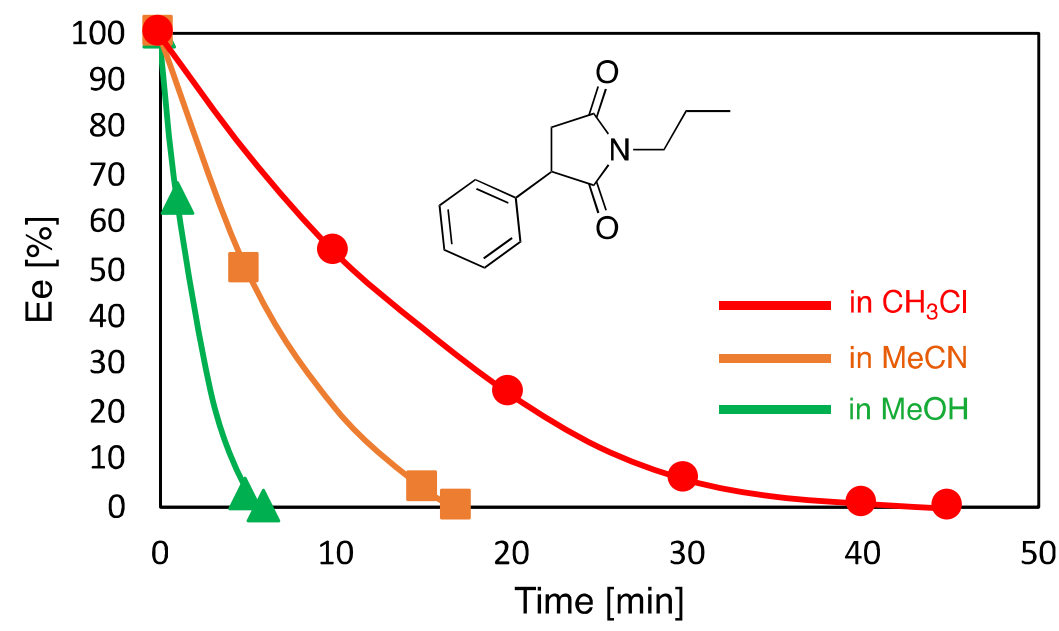

Figure S8. The time course of ee for racemization $1 \mathrm{~b}$ at $20^{\circ} \mathrm{C}$.

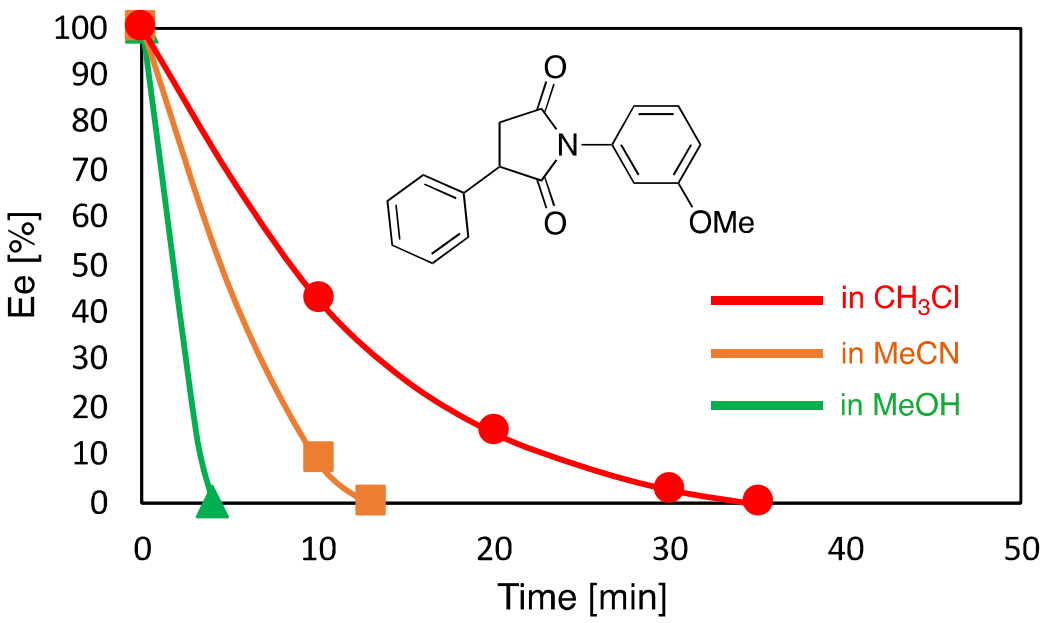

Figure S9. The time course of ee for racemization $1 \mathrm{f}$ at $20^{\circ} \mathrm{C}$. 


\section{Crystallization-induced dynamic optical resolution of $\mathbf{1 b}$ and $\mathbf{1 f}$.}

In a vial, $1 \mathbf{b}$ or $1 \mathrm{f}$ (5 $\mathrm{mg}$ or $100 \mathrm{mg}$ ) and $\mathrm{DBU}(0.5 \mathrm{eq})$ was dissolved in $\mathrm{CHCl}_{3}$ and hexane, and the solvent was slowly evaporated with stirring at $20^{\circ} \mathrm{C}$ until all solvent was evaporated off. Remained solids were subjected to HPLC analysis to determine the enantiomeric purity. Crystals were recovered quantitatively.

\section{Attrition-enhanced deracemization of racemic $1 \mathrm{~b}$ and $1 \mathrm{f}$.}

Attrition-enhanced deracemization of racemic succinimide 1b. In a sealed glass tube (ø25 $\mathrm{mm}), 1 \mathrm{~b}(217 \mathrm{mg}, 1.0 \mathrm{mmol}), 2$-propanol $(0.3 \mathrm{~mL}), \mathrm{DBU}(0.015 \mathrm{~mL}, 0.10 \mathrm{mmol})$, and 20 glass beads ( $\varnothing 2 \mathrm{~mm}$ ) were added and suspended with stirring at $600 \mathrm{rpm}$ using cross shape stirring bar $(15 \mathrm{~mm})$ at $20^{\circ} \mathrm{C}$ for several days. Crystals obtained by filtration were subjected to HPLC (CHIRALPAK IC, Hex:2-PrOH = 80:20, flow $0.5 \mathrm{~mL} / \mathrm{min}, \mathrm{RT}=17.7$ and $26.2 \mathrm{~min}$ ) to determine the enantiomeric purity.

Attrition-enhanced deracemization of racemic 1f. In a sealed glass tube ( $\varnothing 25 \mathrm{~mm}), 1$ f $(281$ $\mathrm{mg}, 1.0 \mathrm{mmol}), \mathrm{EtOH}(0.3 \mathrm{~mL}), \mathrm{DBU}(0.015 \mathrm{~mL}, 0.10 \mathrm{mmol})$, and 20 glass beads $(\varnothing 2 \mathrm{~mm})$ was added and suspended with stirring at $600 \mathrm{rpm}$ using cross shape stirring bar (15 mm) at $40{ }^{\circ} \mathrm{C}$. Crystals obtained by filtration were subjected to HPLC (CHIRALPAK IA, Hex:EtOH = $50: 50$, flow $1.0 \mathrm{~mL} / \mathrm{min}, \mathrm{RT}=14.2$ and $23.5 \mathrm{~min}$ ) to determine the enantiomeric purity. 
UV trace at $254 \mathrm{~nm}$

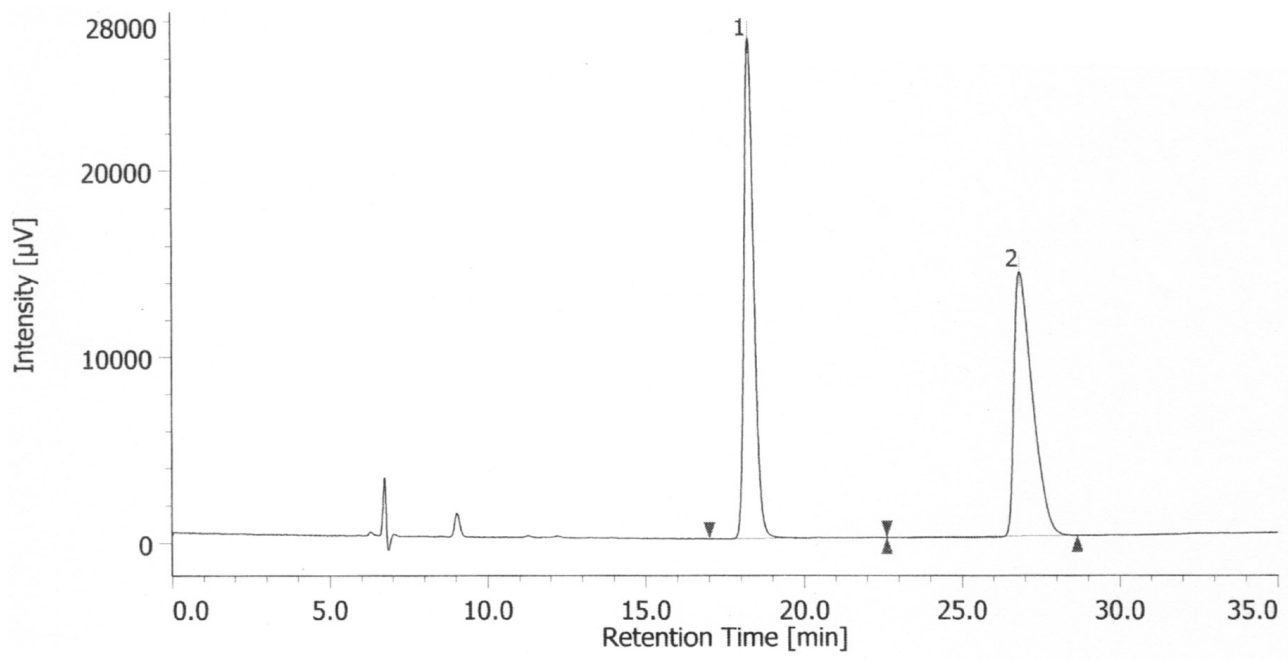

CD trace at $254 \mathrm{~nm}$

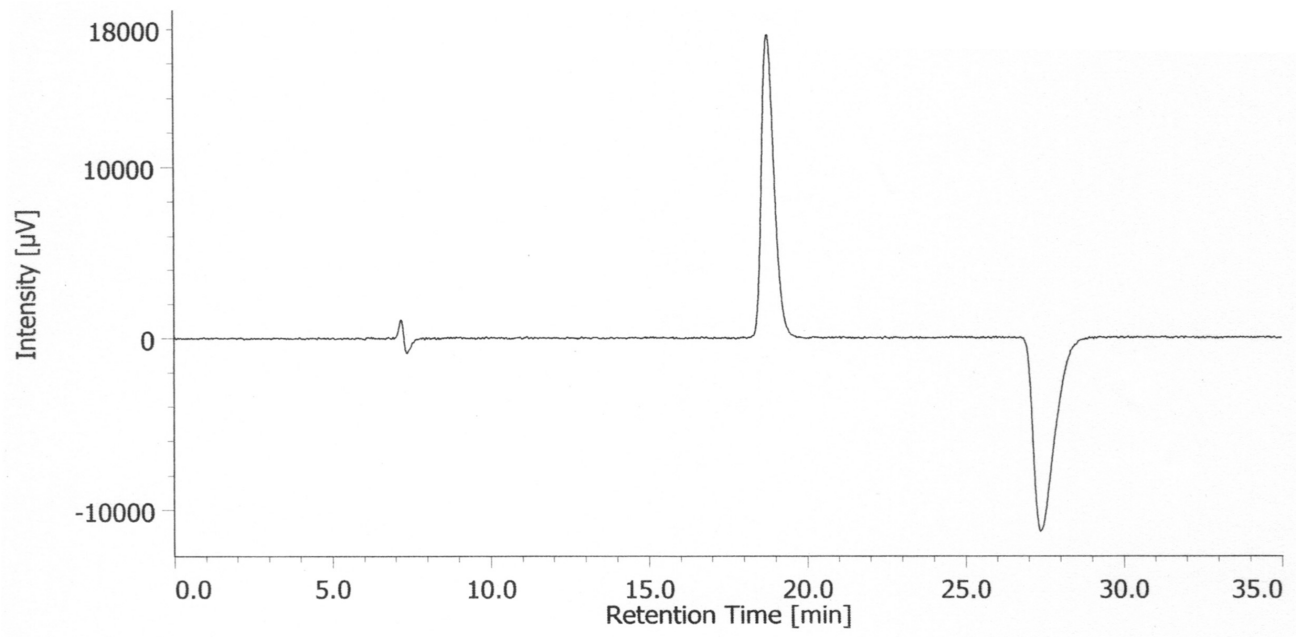

CHIRALPAK IC,

Flow rate: $0.5 \mathrm{~mL} / \mathrm{min}$

Eluent: Hex:2-PrOH = 80:20

Figure S11. HPLC analysis of racemic $\mathbf{1 b}$ 
UV trace at $254 \mathrm{~nm}$

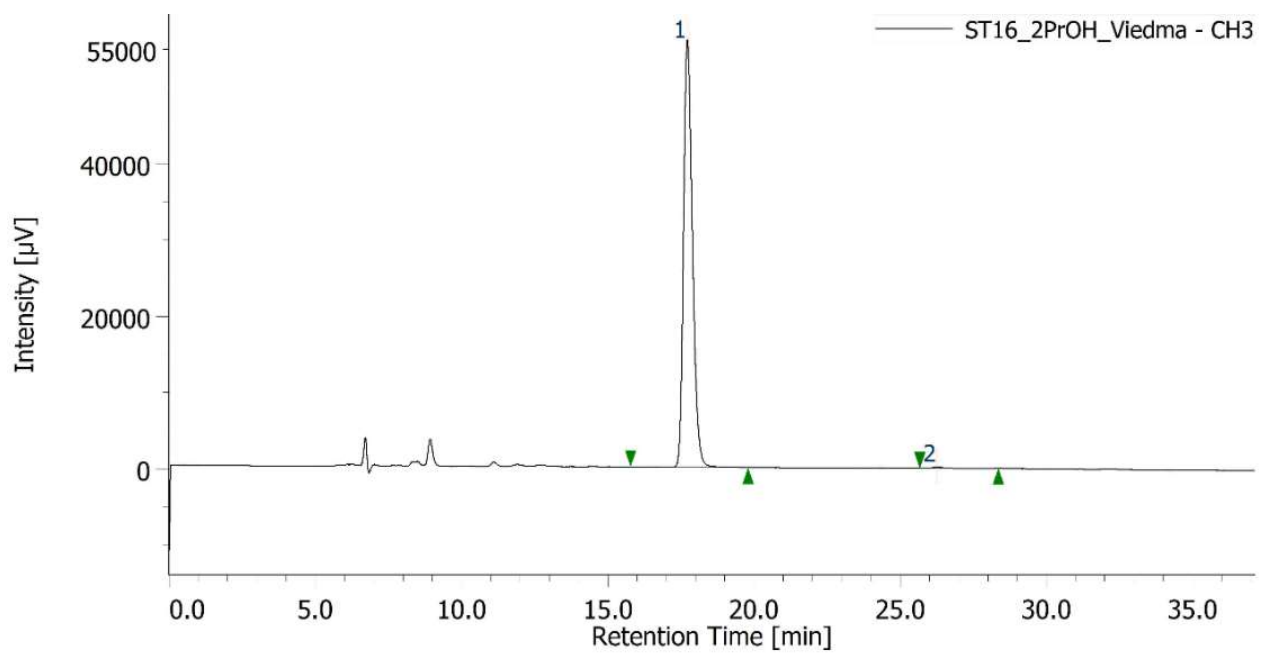

CD trace at $254 \mathrm{~nm}$

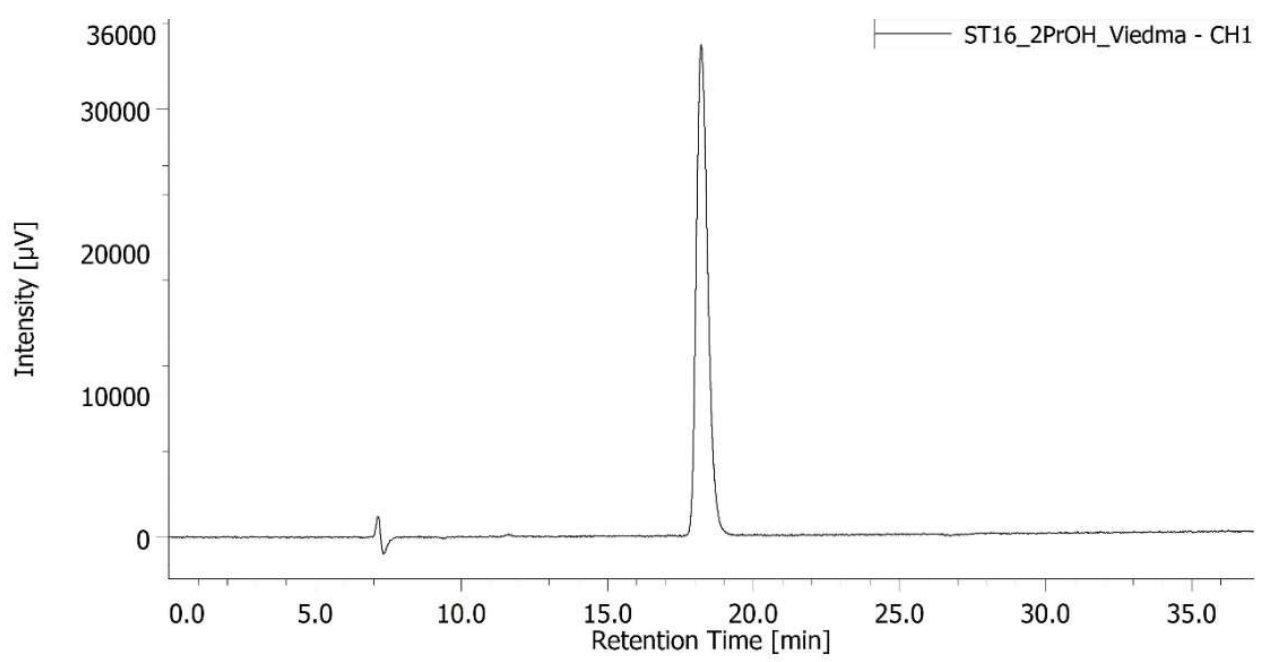

CHIRALPAK IC,

Flow rate: $0.5 \mathrm{~mL} / \mathrm{min}$

Eluent: Hex:2-PrOH = 80:20

Figure S12. HPLC analysis of 1b in $99 \%$ ee 
UV trace at $254 \mathrm{~nm}$

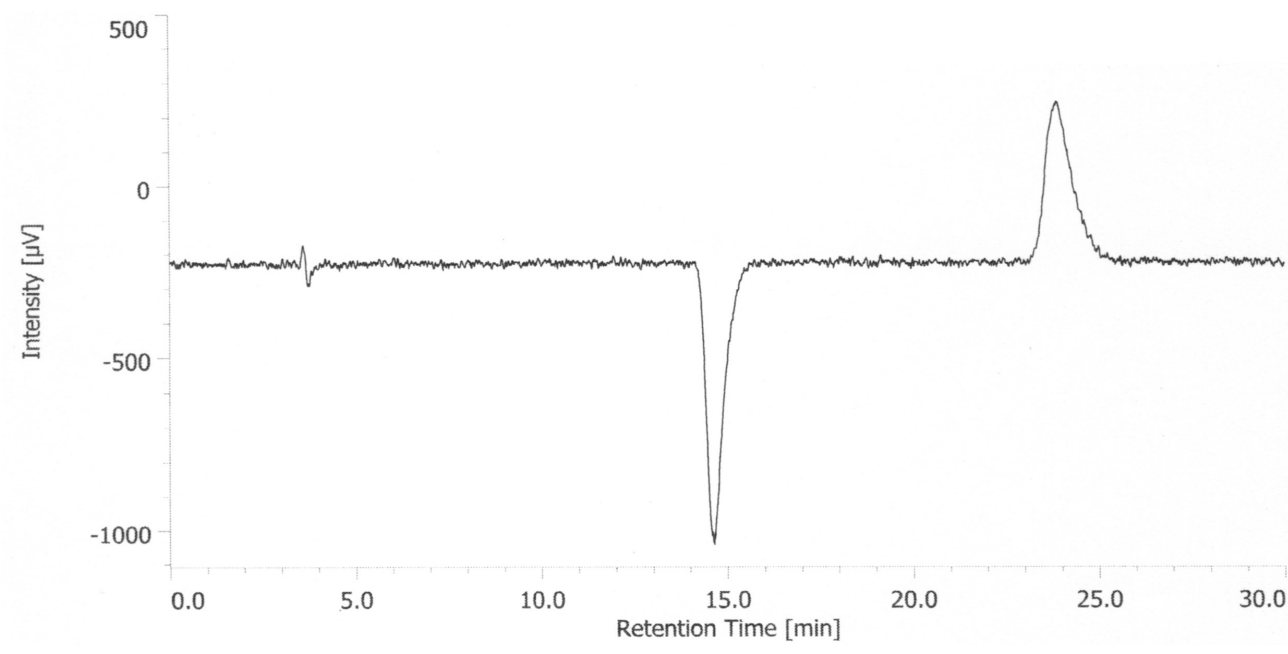

CD trace at $254 \mathrm{~nm}$

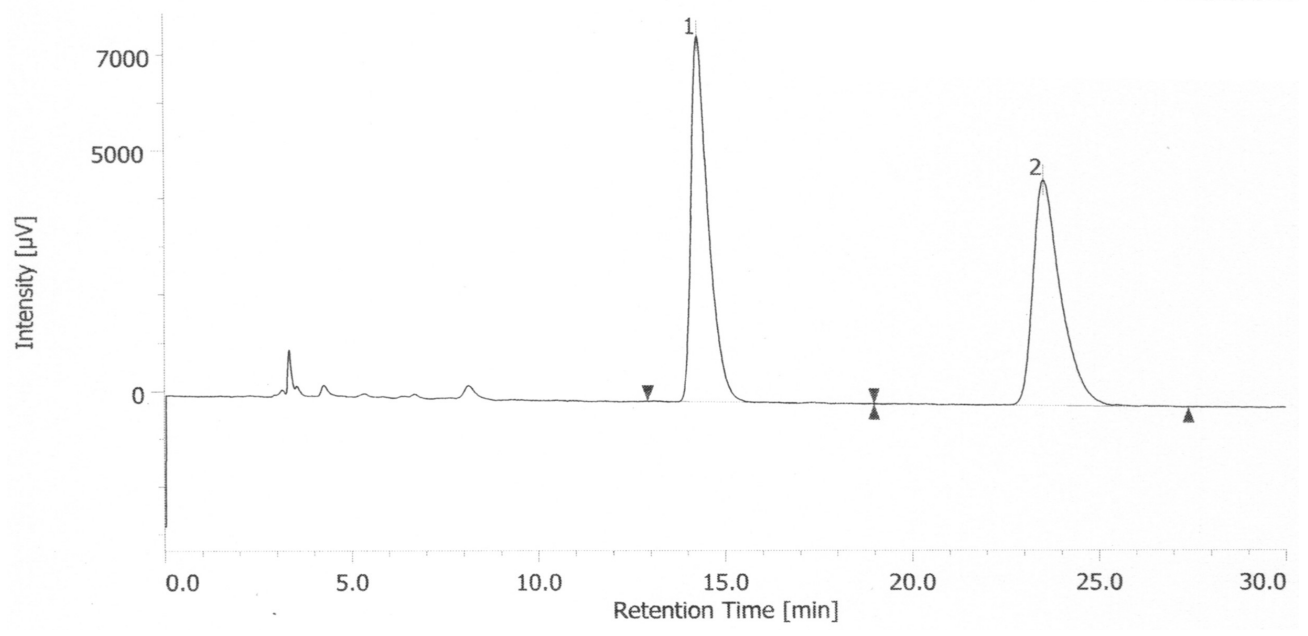

CHIRALPAK IA,

Flow rate: $1.0 \mathrm{~mL} / \mathrm{min}$

Eluent: Hex:EtOH $=50: 50$

Figure S13. HPLC analysis of racemic 1f 
UV trace at $254 \mathrm{~nm}$

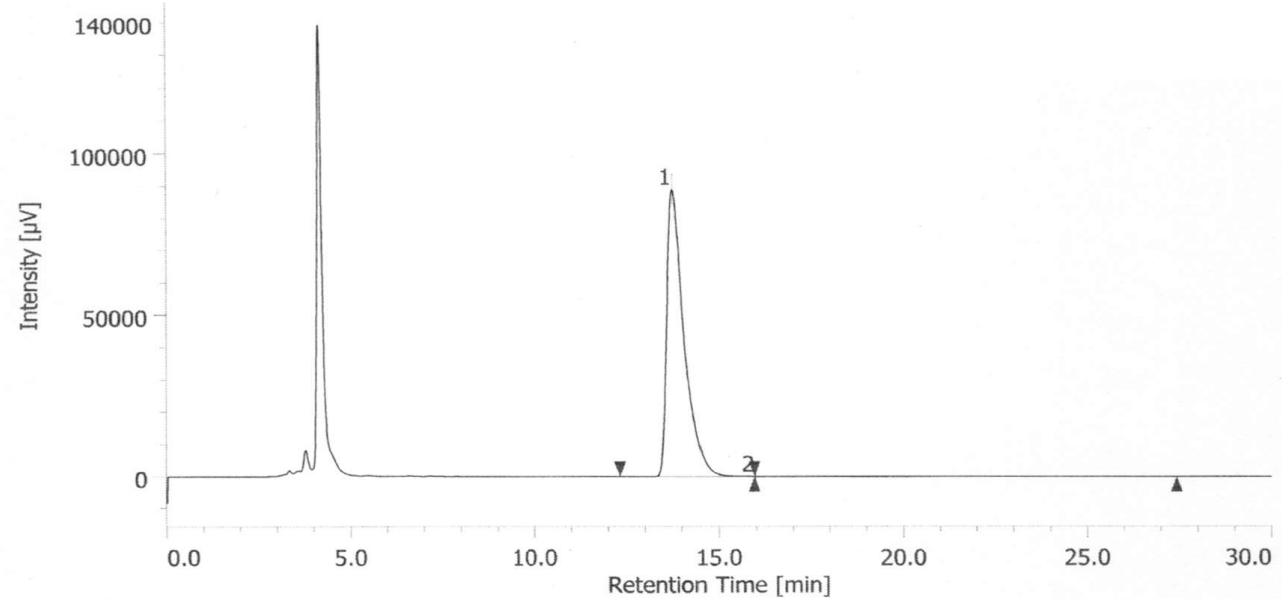

CD trace at $254 \mathrm{~nm}$

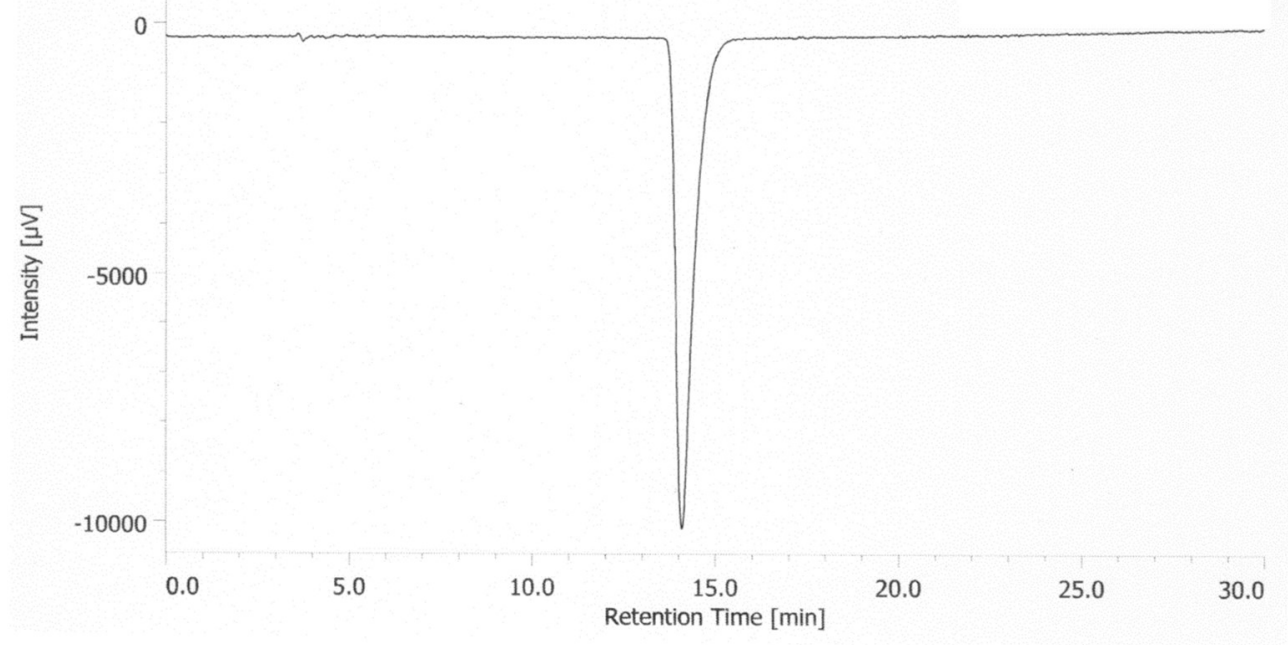

CHIRALPAK IA,

Flow rate: $1.0 \mathrm{~mL} / \mathrm{min}$

Eluent: Hex:EtOH = 50:50

Figure S14. HPLC analysis of $\mathbf{1 f}$ in $99 \%$ ee 
Figure $\mathbf{S} 15 .{ }^{1} \mathrm{H}-\mathrm{NMR}$ of $\mathbf{1 b}$
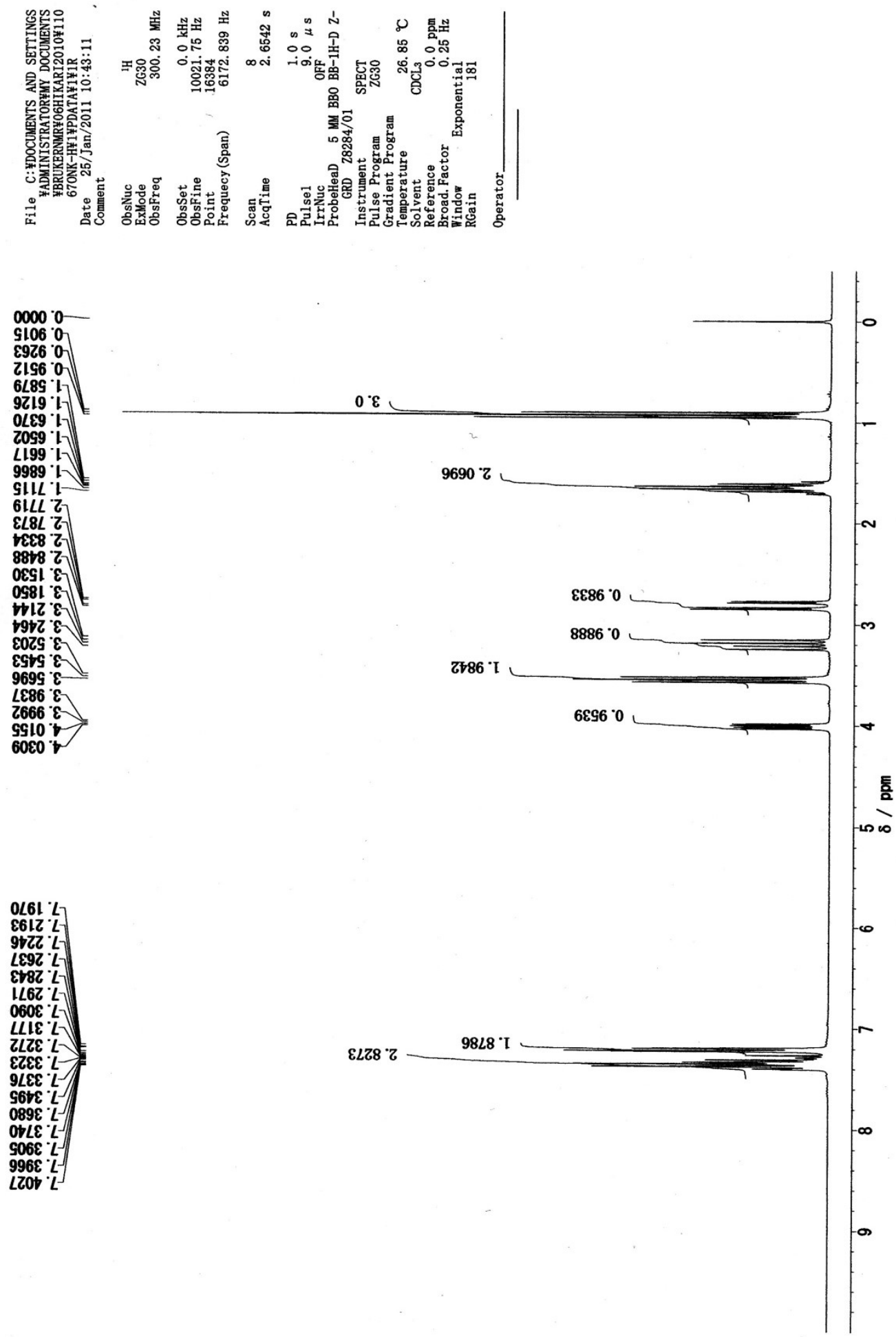
Figure $\mathbf{S} 16 .{ }^{13} \mathrm{C}-\mathrm{NMR}$ of $\mathbf{1 b}$

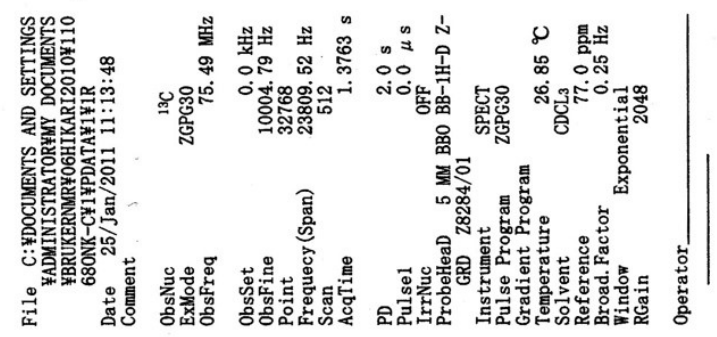

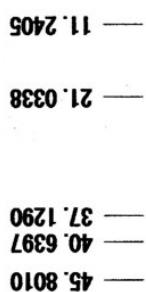

$99 L 9.9 L$

$0000 \cdot L L$

SEZt LL

gGLZ LZT

$8698 . \mathrm{LVI}-$

$\varepsilon Z 9 \varepsilon \cdot\llcorner\varepsilon 1-$

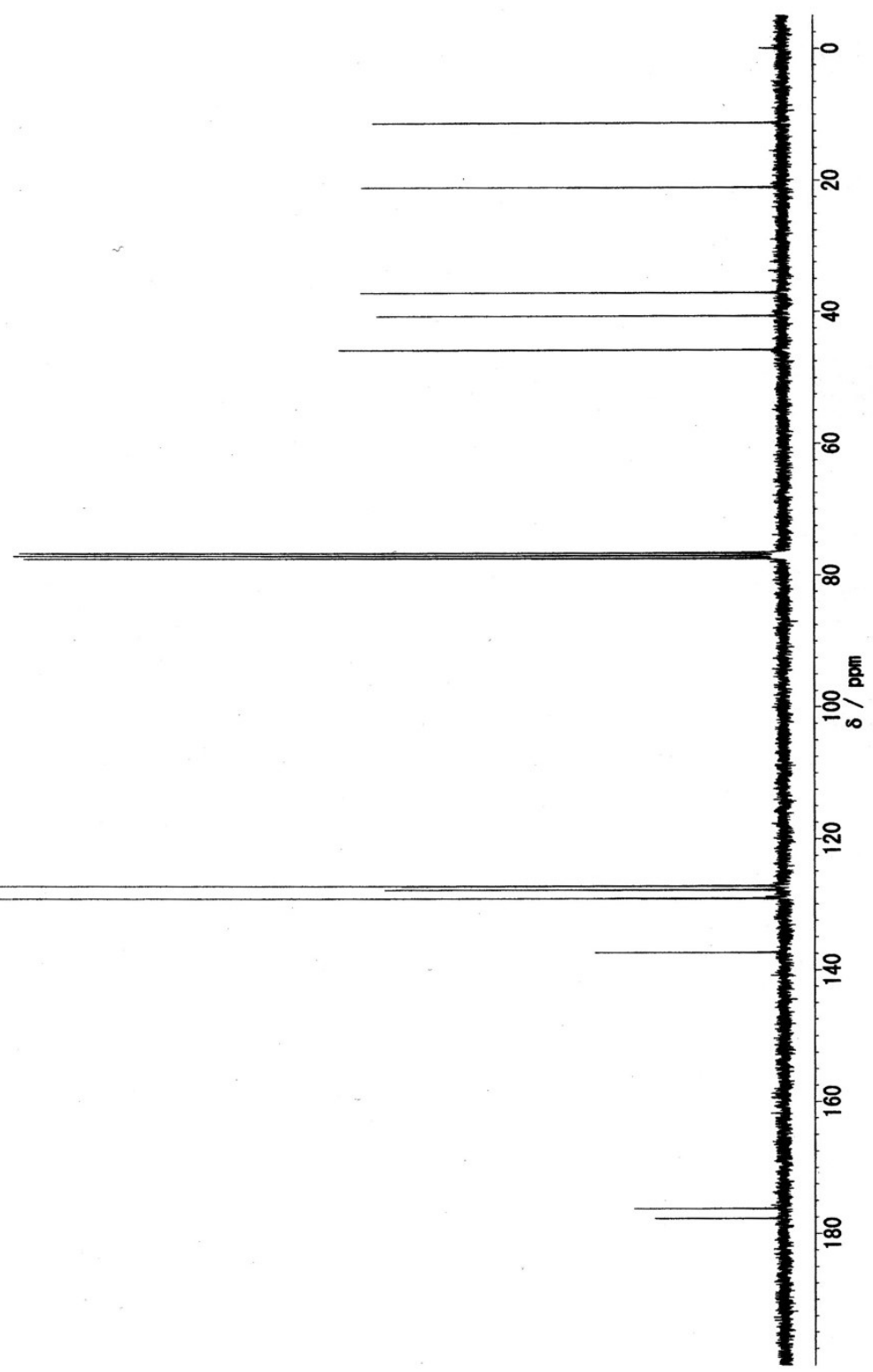

SLZ2 $9 L 1=$ 
Figure S17. ${ }^{1} \mathrm{H}-\mathrm{NMR}$ of $\mathbf{1 f}$

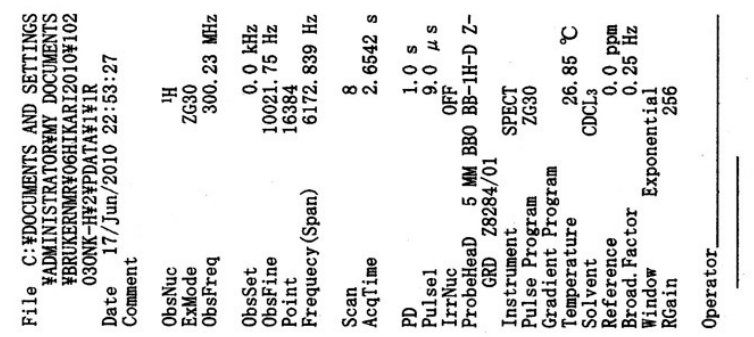

$0000 \%$

$t<19^{\circ} 1-$
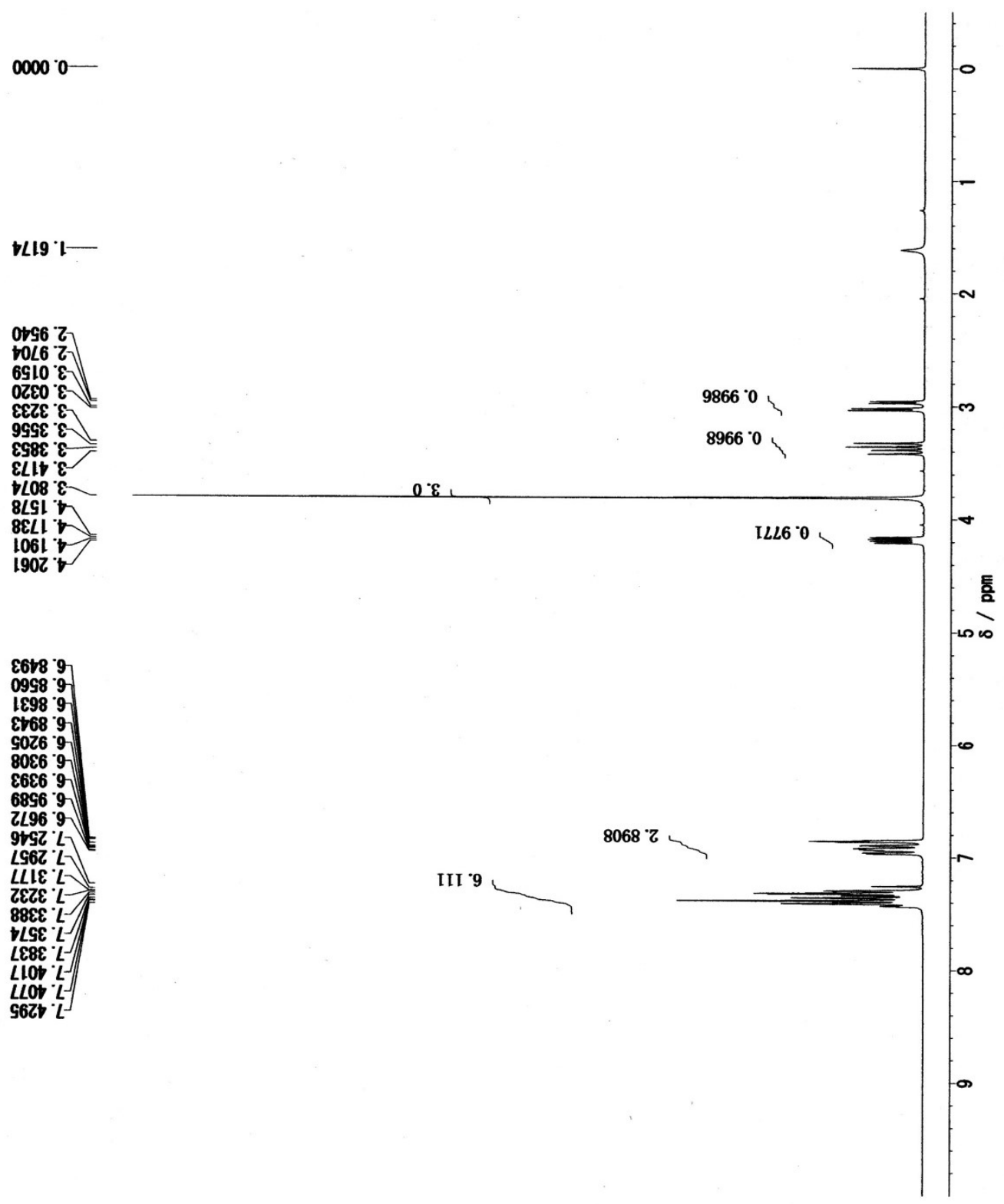
Figure $\mathrm{S} 18 .{ }^{13} \mathrm{C}-\mathrm{NMR}$ of $\mathbf{1 f}$
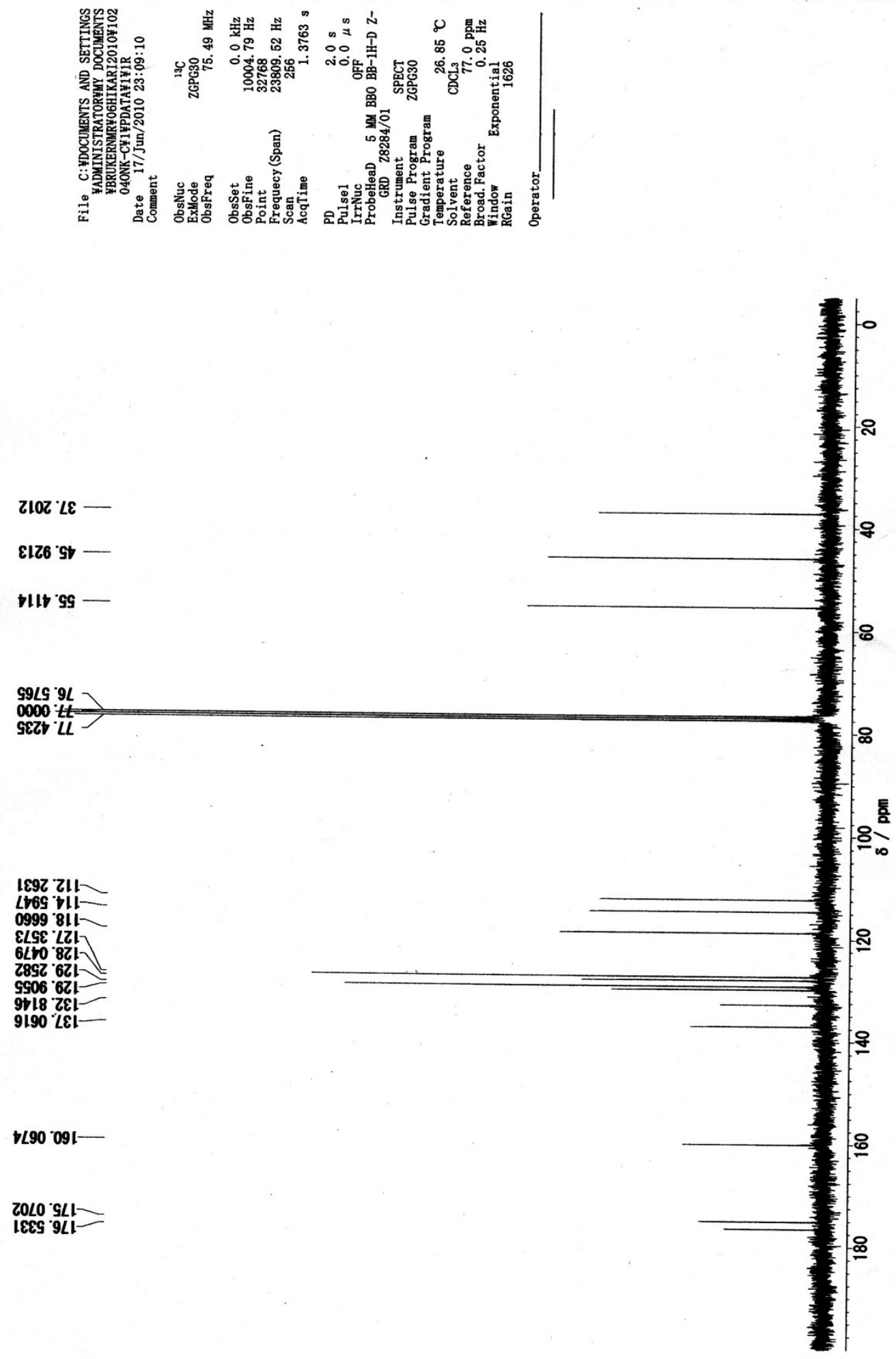